\title{
Vegetation Inventory and Rare Plant Survey of Devonshire Beach-Lesser Slave Lake Provincial Park
}

Submitted to:

Parks and Protected Areas Division

Room 1301 Box 18, Provincial Building $10320-99^{\text {th }}$ Street

Grande Prairie, AB

Submitted by:

Geowest Environmental Consultants Ltd. Suite 203, 4208-97 Street

Edmonton, $\mathrm{AB}$ T6E $5 Z 9$

September, 2004
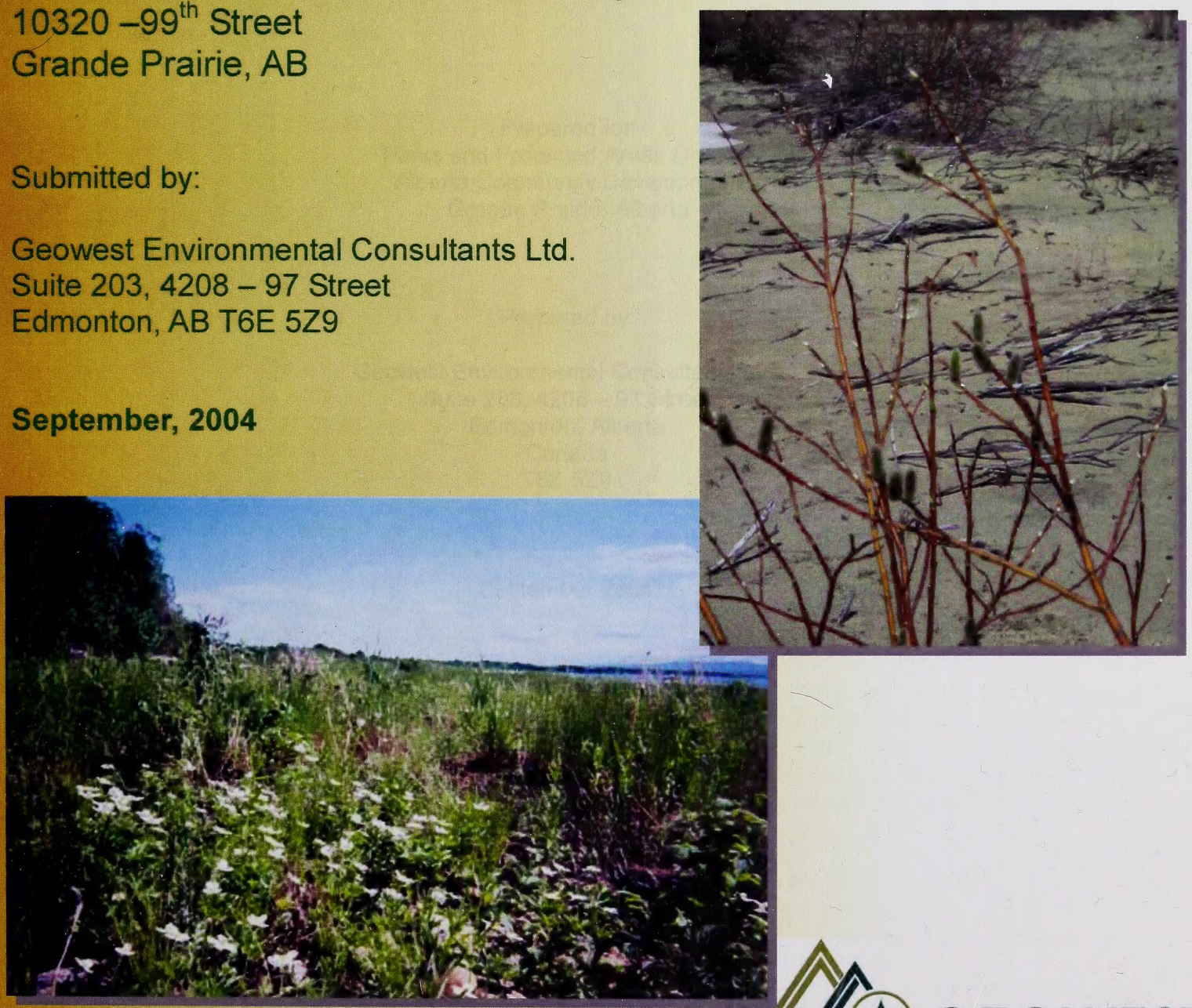
[

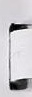

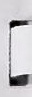

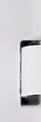

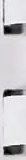

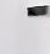

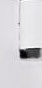

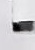

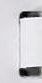

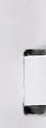
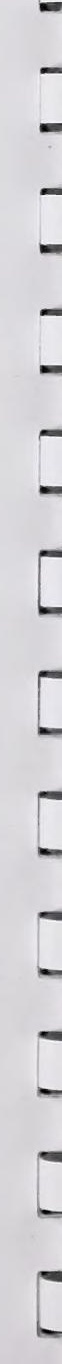


\section{Executive Summary}

During the spring and summer of 2004 Geowest Environmental Consultants (Geowest) completed a biophysical inventory of the Devonshire Beach area for Alberta Community Development, Parks and Protected Areas Division (Client). The study was designed to collect field data and review existing literature on the Devonshire Beach study area in order to provide background materials in support of the development of a management plan for Devonshire Beach. The community of Slave Lake, the Municipal District of Lesser Slave River \#124, and other stakeholders were consulted during this process.

This biophysical study has been structured into two components, the Beach Ridge Significance Study, and the Vegetation Inventory and Rare Plant Survey. Both components are closely linked, as the vegetation growing in the area is influenced by the presence of the beach ridge, and the development of the sand dune is influenced by the vegetation.

The main objectives of the vegetation inventory and rare plant survey include:

- Completing an inventory of plant species in the study area including vascular plants, mosses and liverworts;

- Conducting a survey for the presence of rare and unusual species on Devonshire Beach; and

- Evaluating the vegetation reclamation plots along the beach ridge.

This report details the findings of the vegetation inventory and rare plant study.

The identification of Sitka willow (Salix sitchensis) on Devonshire Beach by Dr. George Argus and Joyce Gould in 2003 indicated the need for a rare plant survey of this unique habitat. Sitka willow is rare in Alberta and is ranked S1 by the Alberta Natural Heritage Information Centre (ANHIC)(Vujnovic and Gould 2002). The population on Devonshire Beach represents one of only two known locations in Alberta for this species; the other record being from the Whitecourt area in 1968 (ANHIC files 2004).

A literature search was completed to locate references relating to Lesser Slave Lake Provincial Park and sand dune communities in northern Alberta. Field surveys were conducted three times during the months of May through August 2004. Field crews performed a reconnaissance survey of the study area and defined three main habitat types; (1) forested partially stabilized dune and slope, (2) lower slope active sand, and (3) beach habitats. The vegetation inventory and rare plant surveys were conducting by using a random meander walk within each habitat type and compiling a species list until no new species were found. A total of 193 vascular plant, moss and liverwort species were encountered during the three site visits to Devonshire Beach. Three rare species were observed, including a likely observation of the Sitka willow (Salix sitchensis) ranked S1 by ANHIC, a confirmed population of fox sedge (Carex vulpinoidea) along the shoreline of Lesser Slave Lake (ranked S2) and a patch of Campylium hispidulum (false willow moss) ranked S3. A number of invasive species were found including three noxious weeds (under the Alberta Weed Act), five nuisance weed species, six non-native species considered by the Alberta Native Plant Council to be invasive and five non-native species likely introduced through past reclamation efforts. One unusual grass species was encountered, however the identification is not entirely certain.

During the early 1970's, it became evident that Devonshire Beach and the associated beach ridge in Lesser Slave Lake Provincial Park were extensively disturbed by recreational over-use and sand excavation for highway construction. Consequently, portions of the beach ridge system were completely denuded of native vegetation, causing sand to shift eastward from Lesser Slave Lake (Lesko 1974). A major reclamation program was initiated in 1973, which attempted to mechanically stabilize sand on the beach ridge and re-establish vegetation to ensure that sand 
movement was minimized. A second evaluation of reclamation on the beach ridge was conducted in 1996 as part of a horticultural plan for the Big Lake Discovery Centre (BKA 1996).

The 1973 and 1996 reclamation efforts were re-evaluated as part of the 2004 field program. During the field surveys, several sections of wood-lathe snow fencing were encountered, primarily in the southern portion of Devonshire Beach. Sand movement was evident around all portions of the fencing although vegetation was also present. Many of the species observed were species native to Alberta, however certain species are more common in the southern portion of the province. The 1996 reclamation site was investigated thoroughly, however it was difficult to determine where the reclamation plot ended and where the natural beach ridge began. While the snow fence was evident, the use of native species in reclamation attempts made determining the extents of the reclamation plot difficult.

As a result of the literature review and field surveys, several recommendations are proposed, including:

1. Invasive Species Monitoring / Vegetation Management Program

2. Additional Rare Plant / Rare Community Surveys

3. Dedicated Non-vascular / Bryophyte Survey

4. Rare Species Monitoring Program

5. Surveys on Leeward Side of Dune / Wetland Complex

6. Formal Re-vegetation Program 


\section{Table of Contents}

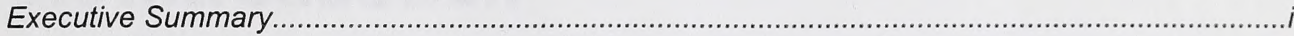

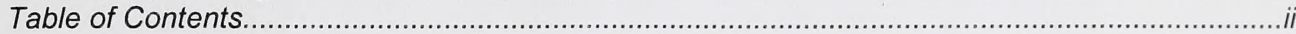

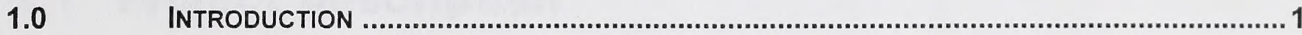

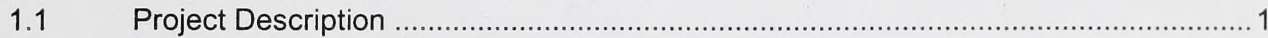

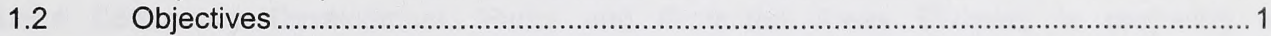

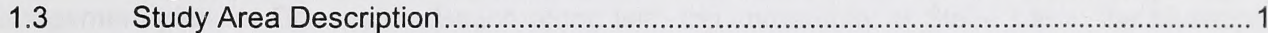

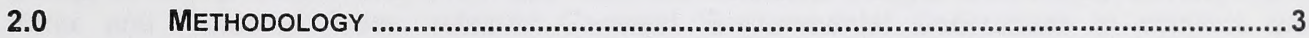

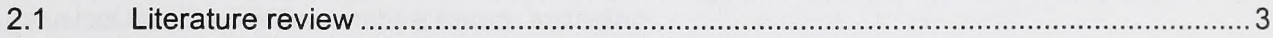

$2.2 \quad$ Plant Inventory and Rare Plant Survey ....................................................... 3

2.2.1 Background Information ................................................................................ 3

2.2.2 Vegetation and Rare Plant Field Survey Methods ............................................ 4

$2.3 \quad$ Non-Native, Invasives and Agronomic Species .............................................. 4

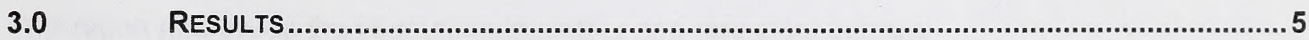

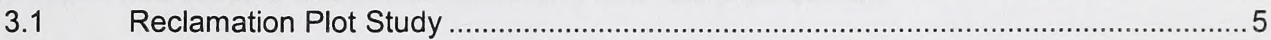

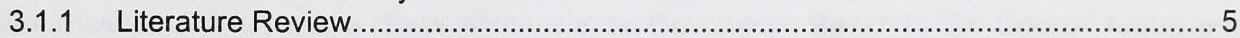

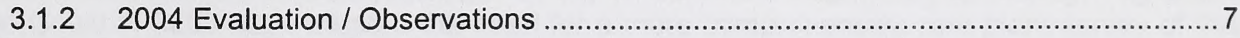

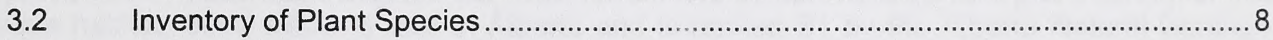

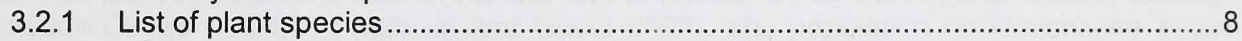

3.2.2 List and discussion of non-native plant species ............................................ 12

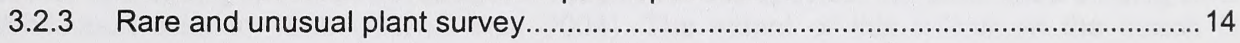

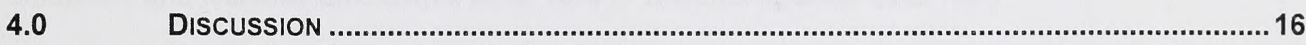

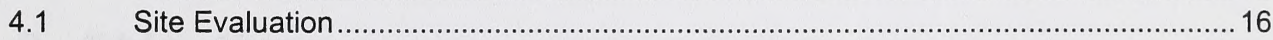

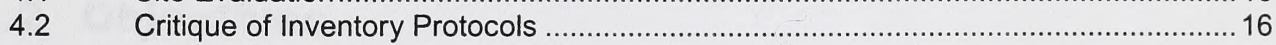

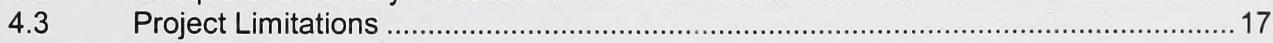

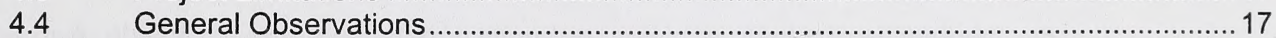

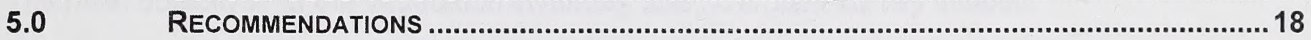

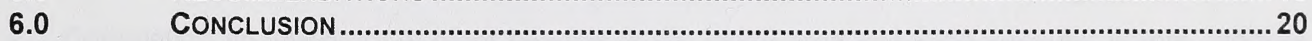

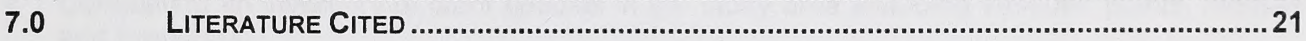

\section{List of Tables}

Table 1. Alberta Natural Heritage Information Centre (ANHIC) Rankings.................................... 3

Table 2. Devonshire beach vegetation survey dates........................................................... 4

Table 3. Grass and legume species used in 1970's reclamation (after Lesko, 1974) ................... 5

Table 4. Native plant species used in 1996 reclamation program (BKA 1996) ........................... 6

Table 5. Complete list of plant species from the 2004 biophysical inventory. .............................. 8

Table 6. Non-native, invasive and designated weed species found in the Devonshire Beach study area.......

\section{Appendices}

Appendix 1 - List of Plant Species by Habitat Type

Appendix 2 - Rare Plant Population Locations

Appendix 3 - Map of Joyce Gould's June 2004 Survey Results 


\subsection{Introduction}

\subsection{Project Description}

Alberta Community Development, Parks and Protected Areas Division, is preparing a management plan for Devonshire Beach along with the community of Slave Lake, the Municipal District of Lesser Slave River \#124, and other stakeholders. Alberta Community Development, Parks and Protected Areas, retained Geowest Environmental Consultants to conduct two biophysical studies for Devonshire Beach including:

- An assessment of the beach ridge to determine its level of significance and disturbance, and

- A vegetation inventory and rare plant survey.

This report addresses the vegetation inventory and rare plant survey.

The identification of Sitka willow (Salix sitchensis) on Devonshire Beach by Dr. George Argus and Joyce Gould in 2003 has indicated the need for a more comprehensive rare plant survey of this unique habitat. Sitka willow is rare in Alberta and is ranked S1 by the Alberta Natural Heritage Information Centre (ANHIC) (Vujnovic and Gould 2002). The population on Devonshire Beach represents one of only two known locations in Alberta for this species; the other record being from the Whitecourt area in 1968 (ANHIC files 2004). The extent of this willow on the beach is unknown, and it is also unknown if other rare or unusual species exist here.

\subsection{Objectives}

The main objectives of the vegetation inventory and rare plant survey include:

- Completing an inventory of plant species in the study area including vascular plants, mosses and liverworts;

- Conducting a survey for the presence of rare and unusual species on Devonshire Beach. Rare species are those on the ANHIC tracking and watch lists. Unusual species include disjunct populations, those at the edge of their range, and regionally uncommon species; and

- Evaluating the vegetation reclamation plot along the beach ridge.

The results of this study may provide information for the preparation of the Devonshire Beach management plan.

\subsection{Study Area Description}

Devonshire Beach is found within Lesser Slave Lake Provincial Park, situated on the eastern edge of Lesser Slave Lake. Lesser Slave Lake is the largest accessible lake in Alberta, located approximately $250 \mathrm{~km}$ northwest of Edmonton. The park was established in 1966.

The Devonshire Beach study area is situated within the Dry Mixedwood Natural Subregion of Alberta. Aspen, balsam poplar, white birch, white spruce and balsam fir dominate typical upland sites in the Dry Mixedwood with mixedwood stands being most common. Beaked hazelnut, low- 
bush cranberry, prickly rose, green alder, bunchberry, wild sarsaparilla and dewberry are common understory species. Dry and sandy sites are typically dominated by jack pine. Black spruce and tamarack tend to dominate forested wetland areas (Beckingham and Archibald 1996).

A previous biophysical inventory and resource assessment of Lesser Slave Lake Provincial Park (Bradley 1980) identified Devonshire Beach and the beach ridge / sand dune / wetland complexes as significant natural features. Both were identified as unique habitats and features of provincial significance.

'The beach ridge and sand dunes within the park combined with the series of ancient beach ridges and large wetlands adjacent to the southern end of the park are a provincially significant geomorphic and biological resource. The complex represents successive post-glacial shorelines and the isolation and infilling of a large bay of Lesser Slave Lake. '(Bradley 1980)

Widely fluctuating water levels are considered important in maintaining the fine sand beaches at the east end of the lake, including Devonshire Beach. The combination of high water levels and high-energy storms contribute large amounts of sand from headlands into the longshore drift that is later deposited on the beaches (Bradley 1980). This process replenishes the beach sand, which is continually eroded by wind. Periodic high water levels also impede vegetation from establishing on the beaches (Bradley 1980). 


\subsection{Methodology}

\subsection{Literature review}

A literature search was completed to locate references relating to Lesser Slave Lake Provincial Park and sand dune communities in northern Alberta. Elaine Nepstad of Alberta Community Development provided many useful references.

\subsection{Plant Inventory and Rare Plant Survey}

\subsubsection{Background Information}

Rare plant species are defined as species that exist in small numbers or have a limited global or provincial distribution, either due to biological characteristics or other reasons (Lancaster 2000). ANHIC ranks, maps and tracks rare plants that are found in Alberta (Vujnovic and Gould 2002). A description of ANHIC rankings is presented in Table 1. For the objectives of this study, a ranking of "rare" refers to ANHIC definitions; specifically S1, S2, and occasionally S3 species. Some species are given a combined rank (i.e., S2/S3) to reflect uncertainty in their status.

Table 1. Alberta Natural Heritage Information Centre (ANHIC) Rankings.

\begin{tabular}{|c|l|}
\hline Provincial Rank & \multicolumn{1}{c|}{ Definition } \\
\hline S1 & Five or less recorded occurrences, or with few individuals remaining. \\
\hline S2 & Six to twenty occurrences or with many individuals in fewer occurrences. \\
\hline S3 & $\begin{array}{l}\text { Twenty-one to one hundred occurrences and may be rare and local } \\
\text { throughout its range, or its range may be restricted (may be abundant at } \\
\text { some locations or may be vulnerable to extirpation because of some factor } \\
\text { of its biology). }\end{array}$ \\
\hline S4 & $\begin{array}{l}\text { Secure under present conditions and typically with greater than one } \\
\text { hundred occurrences or may be fewer with many large populations. May } \\
\text { also be rare in parts of its range, especially at the periphery. }\end{array}$ \\
\hline S5 & $\begin{array}{l}\text { Secure under present conditions with greater than one hundred } \\
\text { occurrences but may be rare in part of its range, especially the periphery. }\end{array}$ \\
\hline
\end{tabular}

Source: Vujnovic and Gould 2002

Species with S1 to S2/S3 are included on ANHIC's 'tracking list'. The ANHIC 'watch list' includes species not present on the tracking list, but for which additional information is desired. Species included on watch lists generally have S3 and S3/S4 ranks and are typically species with a restricted distribution within Alberta, but are common within their range. Consequently, any observed declines in population numbers can result in the movement of a species from the watch to the tracking list (Vujnovic and Gould 2002).

Prior to the field survey program, botanists obtained a list of rare vascular plants from ANHIC's tracking list within the Boreal Forest Natural Region Although information on species that are likely to occur in the area had been developed, the full Tracking and Watch List for vascular plant species (Vujnovic and Gould 2002) was used for the surveys. Furthermore, ANHIC's database was queried to obtain known rare plant occurrences from the study area and from surrounding regions. 


\subsubsection{Vegetation and Rare Plant Field Survey Methods}

The phenology or development of diagnostic floral characteristics for different plant species over the course of a growing season dictates that several surveys are required to positively identify the range of species that may be found in the study area (Lancaster 2000). This was essential for identifying the Sitka willow; catkins are required for the accurate identification of willow species and these are commonly produced prior to leaf flush. Table 2 provides the dates for each of the three rare plant / vegetation surveys that were completed by Geowest personnel.

Table 2. Devonshire beach vegetation survey dates.

\begin{tabular}{|l|l|}
\hline Season & Survey Date \\
\hline Spring & May $17^{\text {th }}$ and $18^{\text {th }}$ \\
\hline Early Summer & June $25^{\text {th }}$ and $26^{\text {th }}$ \\
\hline Late Summer & August $12^{\text {th }}$ \\
\hline
\end{tabular}

Field crews performed a reconnaissance survey of the study area and defined three main habitat types; (1) forested partially stabilized dune and slope, (2) lower slope active sand, and (3) beach habitats. The vegetation inventory and rare plant surveys were conducted by using a random meander walk within each habitat type and compiling a species list until no new species were found. Specimens requiring further examination or species confirmation were collected, with the exception of immature species where the seed heads or flowers required for identification to species level were unavailable or where plant populations were small (no more than 1 in 20) (Lancaster 2000). Taxonomic nomenclature follows Moss (1983) for common species and Vujnovic and Gould (2002) for rare plants. Jennifer Doubt, at the Devonian Botanical Garden, identified unknown mosses. Dorothy Fabian at the University of Alberta Vascular Plant Herbarium identified unknown vascular plants.

\subsection{Non-Native, Invasives and Agronomic Species}

Non-native and invasive plant species were noted as part of rare plant surveys. The general location and population sizes for non-native and invasive plant species were noted during the field surveys. 


\subsection{Results}

\subsection{Reclamation Plot Study}

During the 1970's, it became evident that Devonshire Beach and the associated beach ridge in Lesser Slave Lake Provincial Park were extensively disturbed by recreational over-use and sand excavation for highway construction. Consequently, portions of the beach ridge system were completely denuded of native vegetation, causing sand to shift eastward from Lesser Slave Lake (Lesko 1974). A major reclamation program was initiated in 1973, which attempted to mechanically stabilize sand on the beach ridge and re-establish vegetation to ensure the sand movement was minimized. A second evaluation of reclamation on the beach ridge was conducted in 1996 as part of a horticultural plan for the Big Lake Discovery Centre (BKA and Turner 1996). The results of these are discussed below.

\subsubsection{Literature Review}

Lesser Slave Lake Provincial Parks' staff attempted to stabilize the open disturbed sand with snow fences installed parallel to the lakeshore. The fences helped to accumulate sand but did not stop sand movement entirely. The area was seeded with a mixture of seeds, as there was little information on sand dune reclamation in Alberta (Lesko 1974). Fourteen grass species, five legumes and five woody species were tested in four different topographic positions on the sand dunes. The grasses and legumes used in the reclamation trials are summarized in Table 3 . Only four of the species used were native to Alberta, including Agropyron dasystachyum, Festuca scabrella, Calamovilfa longifolia and Oryzopsis hymenoides.

Table 3. Grass and legume species used in 1970's reclamation (after Lesko, 1974).

\begin{tabular}{|c|c|}
\hline Species & Common Name \\
\hline Agropyron cristatum (L.) Gaertn. & Fairway wheatgrass* \\
\hline Agropyron dasystachyum (Hook.) Scrib. & Thick spike wheatgrass \\
\hline Agropyron trichophorum (Link) Richt. & Pubescent wheatgrass* \\
\hline Agropyron desertorum (Fisch.) Schult. & Nordan wheatgrass ${ }^{*}$ \\
\hline Festuca rubra L. & Red fescue* \\
\hline Festuca scabrella Torr. & Rough fescue \\
\hline Festuca ovina var. duriuscula A.Gray & Hard fescue* \\
\hline Festuca arundinacea Schreb. & Alberta fescue* \\
\hline Lolium perenne L. & Perennial ryegrass* \\
\hline Poa compressa L. & Canada bluegrass* \\
\hline Poa glaucantha Gaudin & Bluegrass* \\
\hline Calamovilfa longifolia (Hook.) Scribn. & Prairie sandreed \\
\hline Oryzopsis hymenoides (Roem. and Schult.) Ricker & Indian ricegrass \\
\hline Elymus junceus Fisch. & Russian wild-rye* \\
\hline Melilotus spp. & Sweet clover* \\
\hline Astragalus cicer $\mathrm{L}$. & Cicer milk vetch ${ }^{\star}$ \\
\hline Coronilla varia $L$. & Crown vetch ${ }^{*}$ \\
\hline Onobrychis sativa Lam & Sainfoin* \\
\hline Lotus corniculatus L. & Bird's Foot Trefoil* \\
\hline
\end{tabular}

${ }^{*}=$ Non-native plant species 
Cuttings of willow (Salix spp.), sage (Artemisia spp.), saskatoon (Amelanchier alnifolia) and balsam poplar were also collected locally and planted in the reclamation areas. Transplanted saskatoon seedlings and Artemisia cuttings survived relatively well while poplar and willow cuttings performed poorly (Lesko 1974). The most successful grasses after a year of observation were Russian wild-rye (Elymus junceus), native sod clumps (Elymus innovatus) and nordan wheatgrass (Agropyron desertorum) (Lesko 1974).

A second evaluation of the reclamation plots was conducted in 1996 as part of a horticultural plan for the Big Lake Discovery Centre (BKA and Turner1996). During this evaluation, the authors noted that sand deposits of up to $500 \mathrm{~mm}$ (20 inches) had been deposited around remnant snow fences along the beach. The authors suspected that the initial formation of the existing fore-dune deposits were directly related to the initial reclamation program (1971-1975) (BKA and Turner 1996). However, they felt that it was uncertain whether sand deposition resulted from debris and driftwood that was allowed to accumulate in those years or to the installed snow fence, which separated the beach from the vegetated region. Furthermore, they noted that slightly higher lake levels during this period may also have played a significant role in bringing sand deposits further in shore. Furthermore, agronomic and native grasses and legumes planted in the early 1970's were thought to have increased sand stability (BKA and Turner 1996).

The 1996 evaluation determined that a number of blowouts on the lakeside of the beach road had been successfully reclaimed. The authors noted that many transplants of trees and shrubs had established successfully in the previously disturbed areas while there had also been considerable natural encroachment. (BKA and Turner 1996). They noted that the Devonshire Beach lakeside vegetation was much denser than twenty-five years ago, likely due to several factors including higher average water table levels and the fertilization program that was implemented during the 1970 's. The implementation of stairs and walkways and the day use parking lot was also thought have had an effect on reducing sand movement and erosion by focusing traffic on more durable substrates (BKA and Turner 1996).

The 1996 study also evaluated the use of native plant species for reclamation / re-vegetation along the beach ridge. An additional 2.4 metres of snow fence provided by Alberta Parks was installed at the bottom of the blowout located north of the central stairs (lake side). Twelve species of native plants common to the beach, fore dune and wash areas were transplanted in a moderate foot traffic area and are summarized in Table 4. The location also represented a relatively high sand movement / deposition area, being located at the foot of an old blowout (BKA and Turner 1996).

Table 4. Native plant species used in 1996 reclamation program (BKA and Turner 1996).

\begin{tabular}{|l|l|}
\hline Species & Common Name \\
\hline Artemisia spp. & Wormwood / sage \\
\hline Carex spp. & Sedges \\
\hline Epilobium angustifolium & Fireweed \\
\hline Equisetum arvense & Common horsetail \\
\hline Populus balsamifera & Balsam poplar \\
\hline Populus tremuloides & Trembling aspen \\
\hline Prunus pensylvanica & Chokecherry \\
\hline Rosa spp. & Rose \\
\hline Rubus idaeus & Wild red raspberry \\
\hline Salix exigua & Sandbar willow \\
\hline Smilacina stellata & Star-flowered Solomon's seal \\
\hline Solidago spp. & Goldenrod \\
\hline
\end{tabular}




\subsubsection{Evaluation / Observations}

The 1973 and 1996 reclamation efforts were re-evaluated as part of the 2004 field program. However, as neither the 1973 nor 1996 projects were accurately mapped or designated on the ground, only general sites could be visited and observations made. Should future reclamation or stabilization projects be undertaken, it would be useful to have either GPS coordinates of the location or air photos with marked site locations to provide more accurate data and observations.

During the field surveys, several sections of wood-lathe snow fencing were encountered, primarily in the southern portion of Devonshire Beach. Several of the snow fences were thought to be part of the 1970's redevelopment program, while the short section of snow fencing north of the central stairs was thought to be part of the 1996 reclamation program. Sand movement was evident around all portions of the fencing although vegetation was also present. Many of the species observed were species native to Alberta, however certain species are more common in the southern portion of the province, in mixedgrass prairie regions. For example, Indian rice grass (Oryzopsis hymenoides) and sand grass (Calamovilfa longifolia) are grass species that typically occur in open sand in grassland regions of southern Alberta. These species were introduced as part of the 1973 reclamation program and persist to this day. Smaller amounts of rough fescue (Festuca scabrella) were also encountered; however, this species was not as prevalent as the Indian rice grass or the sand grass. Crested wheat-grass (Agropyron pectiniforme / cristatum) was found to be locally abundant in several old blowout sites, however its distribution was fairly limited. The only other introduced species used for reclamation that were encountered during the surveys were sweet clover (Melilotus alba and Melilotus officinale), sheep fescue (Festuca ovina) and Cicer's milkvetch (Astragalus cicer). Both the sweet clover and milkvetch were found in greatest covers along the beach ridge road. The sweet clover was also found in blowout areas and further downslope from the road, while the milkvetch rarely was found more than 2-3 metres away from the road. Sheep fescue was found in a variety of habitats, but it reached its greatest cover along the west-facing beach ridge slope adjacent to more open, former blowout sites. In these sites, sheep fescue often forms a fairly uniform cover, reducing the amount of exposed sand at the ground surface, while the sweet clover and milkvetch was found growing in relatively open exposed sand (i.e. sand ground cover $>50 \%$ ).

The 1996 reclamation site was investigated thoroughly, however it was difficult to determine where the reclamation plot ended and where the natural beach ridge began. While the snow fence was evident, the use of native species in reclamation attempts made determining the extents of the reclamation plot difficult. A greater percentage of exposed sand was evident around the snow fence although this gradually decreased to both the north and south where vegetation covered higher percentages of the ground. However, species found in the blowout area were quite similar to the surrounding natural vegetation although the occasional species mentioned in reclamation reports (i.e. Artemisia campestris, Oryzopsis hymenoides) were encountered. Aspen seedlings, chokecherry, star-flowering Solomon's seal, raspberry and hay sedge were all observed in the reclamation plot vicinity. 


\subsection{Inventory of Plant Species}

A total of 193 vascular plant, moss and liverwort species were encountered during the three site visits to Devonshire Beach. Three rare species were observed, including a likely observation of the Sitka willow (Salix sitchensis) ranked S1 by ANHIC, a confirmed population of fox sedge (Carex vulpinoidea) along the shoreline of Lesser Slave Lake (ranked S2) and a patch of Campylium hispidulum (false willow moss) ranked S3. A number of invasive species were found including three noxious weeds (under the Alberta Weed Act), five nuisance weed species, six non-native species considered by the Alberta Native Plant Council to be invasive and five nonnative species likely introduced through past reclamation efforts. One unusual grass species was encountered, however the identification is not certain. These findings are discussed in further details in the following sections.

\subsubsection{List of plant species}

A complete list of plant species is provided in Table 5. Taxonomic nomenclature follows Moss (1983) with common names following Alberta Energy (1990). Appendix 1 provides a listing of the plant species by habitat type.

Table 5. Complete list of plant species from the 2004 biophysical inventory.

\begin{tabular}{|l|l|}
\hline SCIENTIFIC NAME & COMMON NAME \\
\hline Abies balsamea ((L.) Mill) & Balsam fir \\
\hline Achillea millefolium (L.) & Common yarrow \\
\hline Achillea sibirica (Ledeb.) & Many-flowered yarrow \\
\hline Actaea rubra ((Ait.) Willd.) & Red and white baneberry \\
\hline Agropyron pectiniforme (R. \& S.) & Crested-wheat grass \\
\hline Agropyron repens ((L.) Beauv.) & Quack grass \\
\hline Agrostis scabra (Willd.) & hair grass \\
\hline Agropyron smithii (Rydb.) & Western wheat grass \\
\hline Agrostis stolonifera (L.) & Redtop \\
\hline Agropyron trachycaulum var. subsecundum & Bearded wheat grass \\
\hline Alnus tenuifolia (Nutt.) & River alder \\
\hline Alopecurus aequalis (Sobol.) & Water foxtail \\
\hline Amblystegium serpens & Moss \\
\hline Amelanchier alnifolia (Nutt) & Saskatoon \\
\hline Anemone canadensis (L.) & Canada anemone \\
\hline Anemone multifida (Poir.) & Cut-leaf anemone \\
\hline Apocynum androsaemifolium (L.) & Spreading dogbane \\
\hline Arabis glabra ((L.) Bernh.) & Tower mustard \\
\hline Aralia nudicaulis (L.) & Wild sarsaparilla \\
\hline Arctostaphylos uva-ursi ((L.) Spreng.) & Common bearberry \\
\hline Artemisia campestris (L.) & Plains wormwood \\
\hline Artemisia frigida (Willd.) & Pasture sagewort \\
\hline Aster ciliolatus (Lindl.) & Lindley's aster \\
\hline Aster hesperius (A. Gray) & Western willow aster \\
\hline Aster puniceus (L.) & Purple-stemmed aster \\
\hline Astragalus cicer (L.) & Cicer milk vetch \\
\hline Beckmannia syzigachne ((Steud.) Fern.) & Slough grass \\
\hline Betula papyrifera (Marsh.) & White birch \\
\hline & \\
\hline
\end{tabular}




\begin{tabular}{|c|c|}
\hline SCIENTIFIC NAME & COMMON NAME \\
\hline Brachythecium campestre & Moss \\
\hline Brachythecium salebrosum & Moss \\
\hline Bromus ciliatus (L.) & Fringed brome \\
\hline Bromus inermis var. inermis & Awnless brome \\
\hline Bryohaplocladium microphyllum & Moss \\
\hline Bryum pseudotriquetrum & Moss \\
\hline Bryum spp. & Moss \\
\hline Calamagrostis canadensis ((Michx.) Beauv.) & Bluejoint \\
\hline Calamagrostis inexpansa (A. Gray) & Northern reed grass \\
\hline Calamovilfa longifolia (Hook.) Scribn. & Sand grass \\
\hline Campylium hispidulum & Moss \\
\hline Campanula rotundifolia (L.) & Harebell \\
\hline Cardamine pensylvanica (Muhl) & Bitter cress \\
\hline Carex bebbii (Olney ex Fern.) & Bebb's sedge \\
\hline Carex curta (Good.) & Short sedge \\
\hline Carex deweyana (Schwein) & Dewey's sedge \\
\hline Carex filifolia (Nutt.) & Thread-leaved sedge \\
\hline Carex siccata (Dewey) & Hay sedge \\
\hline Carex vulpinoidea (Michx.) & Fox sedge \\
\hline Carex utriculata (Boott.) & Beaked sedge \\
\hline Ceratodon purpureus ((Hedw.) Brid.) & Moss \\
\hline Chenopodium album (L.) & Lamb's quarters \\
\hline Cicuta maculata (L.) & Water hemlock \\
\hline Cirsium arvense ((L.) Scop.) & Canada thistle \\
\hline Climacium dendroides ((Hedw.) Web \& Mohr.) & Tree Moss \\
\hline Comandra umbellata ((L.) Nutt.) & Bastard toad-flax \\
\hline Conocephalum conicum ((L.) Lindb) & Liverwort \\
\hline Corispermum nitidum (Kit.) & Bugseed \\
\hline Cornus canadensis (L.) & Bunchberry \\
\hline Cornus stolonifera (Michx.) & Red-osier dogwood \\
\hline Corylus cornuta (Marsh.) & Beaked hazeinut \\
\hline Crepis tectorum (L.) & Annual hawk's beard \\
\hline Dactylis glomerata (L.) & Orchard grass \\
\hline Disporum trachycarpum ((S. Wats.) B.\&H.) & Fairybells \\
\hline Drepanocladus aduncus ((Hedw.) Warnst.) & Brown Moss \\
\hline Drepanocladus uncinatus ((Hedw.) Warnst.) & Brown Moss \\
\hline Eleocharis acicularis ((L.) R.\& S.) & Needle spikerush \\
\hline Eleocharis palustis ((L.) R.\&.S) & Creeping spikerush \\
\hline Elymus innovatus (Beal.) & Hairy wild rye \\
\hline Elymus piperi (Bowden) & Giant wild rye \\
\hline Epilobium angustifolium (L.) & Common fireweed \\
\hline Epilobium palustre (L.) & Marsh willowherb \\
\hline Equisetum arvense (L.) & Common horsetail \\
\hline Equisetum fluviatile (L.) & Swamp horsetail \\
\hline Equisetum hyemale (L.) & Common scouring-rush \\
\hline Equisetum pratense (Ehrh.) & Meadow horsetail \\
\hline Erysimum cheiranthoides (L.) & Wormseed mustard \\
\hline
\end{tabular}




\begin{tabular}{|c|c|}
\hline SCIENTIFIC NAME & COMMON NAME \\
\hline Eurhnchium pulchellum ((Hedw.) Jenn.) & Moss \\
\hline Festuca ovina (L.) & Sheep fescue \\
\hline Festuca saximontana (Rydb.) & Rocky mountain fescue \\
\hline Festuca scabrella (Torr.) & Rough fescue \\
\hline Fragaria virginiana (Duchesne) & Wild strawberry \\
\hline Galeopsis tetrahit (L.) & Hemp-nettle \\
\hline Galium boreale (L.) & Northern bedstraw \\
\hline Galium trifidum (L.) & Small bedstraw \\
\hline Galium triflorum (Michx.) & Sweet-scented bedstraw \\
\hline Geocaulon lividum ((Richards) Fern.) & Northern comandra \\
\hline Geum aleppicum (Jacq.) & Yellow avens \\
\hline Geum rivale (L.) & Purple avens \\
\hline Glyceria grandis (S. Wats. ex A. Gray) & Common tall manna grass \\
\hline Glyceria striata ((Lam.) A.S. Hitchc.) & Fowl manna grass \\
\hline Hieracium umbellatum (L.) & Narrow leaved hawkweed \\
\hline Hordeum jubatum (L.) & Foxtail barley \\
\hline Hylocomium splendens ((Hedw.) B.S.G.) & Stair-step Moss \\
\hline Juncus alpinoarticulatus (Chaix.) & Alpine rush \\
\hline Juncus balticus (Willd.) & Wire rush \\
\hline Juncus nodusus (L.) & Knotted rush \\
\hline Juniperus horizontalis (Moench) & Creeping juniper \\
\hline Juniperus communis (L.) & Ground juniper \\
\hline Kochia scoparia ((L.) Schrad.) & Summer cypress \\
\hline Lathyrus ocholeucus (Hook.) & Cream-colored vetchling \\
\hline Ledum groenlandicum (Oeder.) & Common Labrador tea \\
\hline Leptobryum pyriforme & Moss \\
\hline Linnaea borealis (L.) & Twin-flower \\
\hline Lonicera dioica (L.) & Twining honeysuckle \\
\hline Lonicera involucrata ((Richards.) Banks) & Bracted honeysuckle \\
\hline Luzula multiflora ((Retz.) Lej.) & Field woodrush \\
\hline Maianthemum canadense (Desf.) & Wild lily-of-the-valley \\
\hline Medicago sativa (L.) & Alfalfa \\
\hline Melilotus alba (Desr.) & White sweet-clover \\
\hline Melilotus officinalis ((L.) Lam.) & Yellow sweet clover \\
\hline Mentha arvensis (L.) & Wild mint \\
\hline Mertensia paniculata ((Ait.) G.Don) & Large-flowered lungwort \\
\hline Mitella nuda (L.) & Bishop's-cap \\
\hline Mnium spinulosum & Moss \\
\hline Moehringia lateriflora ((L.) Fenzl.) & Blunt-leaved sandwort \\
\hline Orthilia secunda ((L.) House) & One-sided wintergreen \\
\hline Oryzopsis asperifolia (Michx.) & White-grained mountain rice grass \\
\hline Oryzopsis hymenoides ((R.\&S.) Ricker) & Indian rice grass \\
\hline Oryzopsis pungens ((Torr.) A.S. Hitchc.) & Northern rice grass \\
\hline Petasites palmatus ((Ait.) A.Gray) & Palmate-leaved coltsfoot \\
\hline Petasites sagitattus ((Pursh) A.Gray) & Arrow-leaved coltsfoot \\
\hline Phalaris arundinacea (L.) & Reed canary grass \\
\hline Phleum pratense (L.) & Timothy \\
\hline
\end{tabular}




\begin{tabular}{|c|c|}
\hline SCIENTIFIC NAME & COMMON NAME \\
\hline Picea glauca ((Moench) Voss) & White spruce \\
\hline Pinus banksiana (Lamb.) & Jack pine \\
\hline Pinus sylvestris var. sylvestris (L.) & Scot's pine \\
\hline Plagiomnium cuspidatum ((Hedw.) Kop.) & Moss \\
\hline Plantago major (L.) & Common plantain \\
\hline Pleurozium schreberi ((Brid.) Mitt.) & Schreber's Moss \\
\hline Poa palustris (L.) & Fowl bluegrass \\
\hline Poa pratensis (L.) & Kentucky bluegrass \\
\hline Pohlia nutans ((Hedw.) Lindb.) & Copper wire moss \\
\hline Pohlia wahlenbergii ((Web.\&Mohr) Andr.) & Moss \\
\hline Polytrichum juniperum (Hedw.) & Juniper haircap \\
\hline Polygonum lapathifolium (L.) & Pale persicaria \\
\hline Polytrichum piliferum (Hedw.) & Awned haircap \\
\hline Populus balsamifera (L.) & Balsam poplar \\
\hline Populus tremuloides (Michx.) & Aspen \\
\hline Potentilla anserina (L.) & Silverweed \\
\hline Potentilla fruticosa (L.) & Shrubby cinquefoil \\
\hline Potentilla norvegica (L.) & Rough cinquefoil \\
\hline Prunus pensylvanica (L. f.) & Pin cherry \\
\hline Prunus virginiana (L.) & Choke cherry \\
\hline Pylaisiella polyantha ((Hedw.) Grout) & Moss \\
\hline Pyrola asarifolia (Michx.) & Common pink wintergreen \\
\hline Rhytidium rugosum ((Hedw.) Kindb.) & Pipecleaner moss \\
\hline Ribes oxyacanthoides (L.) & Northern gooseberry \\
\hline Ribes triste (Pall.) & Wild red currant \\
\hline Rosa acicularis (Lindl.) & Prickly rose \\
\hline Rosa woodsii (Lindl.) & Common wild rose \\
\hline Rubus idaeus (L.) & Wild red raspberry \\
\hline Rubus pubescens (Raf.) & Dewberry \\
\hline Rumex occidentalis (S.Wats) & Western dock \\
\hline Salix arbusculoides (Anderss.) & Shrubby willow \\
\hline Salix bebbiana (Sarg.) & Beaked willow \\
\hline Salix boothii (Dorn) & Booth's willow \\
\hline Salix candida (Fleugge ex Willd) & Hoary willow \\
\hline Salix drummondiana (Barr. ex. Hook) & Satin willow \\
\hline Salix exigua (L.) & Sandbar willow \\
\hline Salix lasiandra (Benth.) & Western shining willow \\
\hline Salix petiolaris (J.E. Smith) & Basket willow \\
\hline Salix planifolia (Pursh) & Flat leaved willow \\
\hline Salix prolixa (Anderss.) & Mackenzie's willow \\
\hline Salix serissima ((Bailey) Fern.) & Autumn willow \\
\hline Salix sitchensis (Sanson ex Bong.) & Sitka willow \\
\hline Schizachne purpurascens ((Torr.) Swallen) & Purple oat grass \\
\hline Scirpus microcarpus (PresI) & Small fruited bulrush \\
\hline Scirpus validus (Vahl) & Common great bulrush \\
\hline Scutellaria galericulata(L.) & Marsh skullcap \\
\hline Silene cucubalus (Wibel) & Bladder campion \\
\hline
\end{tabular}




\begin{tabular}{|l|l|}
\hline SCIENTIFIC NAME & COMMON NAME \\
\hline Silene noctiflora (L.) & Night-flowering catchfly \\
\hline Sisyrinchium montanum (Greene) & Common blue-eyed grass \\
\hline Smilacina stellata((L.) Desf.) & Star-flowered Solomon's seal \\
\hline Solidago canadensis (L.) & Canada goldenrod \\
\hline Solidago graminifolia (L.) Salisb. & Flat- topped goldenrod \\
\hline Stellaria longifolia (Muhl.) & Long-leaved chickweed \\
\hline Symphoricarpos albus ((L.) Blake) & Snowberry \\
\hline Syntrichia ruralis & Moss \\
\hline Taraxacum officinale (Weber) & Dandelion \\
\hline Tetraphis pellucida (Hedw.) & Moss \\
\hline Thalictrum venulosum (Trem.) & Veiny meadow rue \\
\hline Thuidium abietinum ((Hedw.) B.S.G.) & Moss \\
\hline Tortula mucronifolia & Moss \\
\hline Trientalis borealis (Raf.) & Northern starflower \\
\hline Trifolium hybridum (L.) & Alsike clover \\
\hline Trifolium pratense (L.) & Red clover \\
\hline Trifolium repens (L.) & White clover \\
\hline Typha latifolia (L.) & Common cattail \\
\hline Urtica dioica (L.) & Common nettle \\
\hline Vaccinium myrtilloides (Michx.) & Blueberry \\
\hline Vaccinium vitus-idaea (L.) & Bog cranberry \\
\hline Viburnum edule ((Michx.) Raf.) & Low-bush cranberry \\
\hline Vicia americana (Muhl.) & American vetch \\
\hline Viola adunca (J.E. Smith) & Early blue violet \\
\hline
\end{tabular}

\subsubsection{List and discussion of non-native plant species}

Three noxious weeds were found in the Devonshire Beach study area, highlighted in orange in Table 6; spreading dogbane (Apocynum androsaemifolium), Canada thistle (Cirsium arvense) and bladder campion (Silene cucubalus). Canada thistle was found near the shoreline of Lesser Slave Lake, between the shoreline and the willow thickets west of the walking trail that runs south from the North Shore Day-use area. Several large patches (covering up to 10-15 square metres) were found near willow thickets and Canada thistle formed the dominant ground cover in these sites. Only occasional bladder campion plants were found along the toe slope of the beach ridge and occasionally along the shoreline. Bladder campion was definitely the least common noxious weed found at Devonshire Beach.

Spreading dogbane was found along the walking trail that runs south of the North Shore Day-use area. Several patches were found along the walking trail where spreading dogbane was the dominant species, although it generally occurred sporadically with relatively low percent covers. Although this species is classified as a noxious weed under the Alberta Weed Act (Province of Alberta n.d.), it is a native species to the province. This species is known for its ability to spread rapidly and its potential toxicity to livestock (Tannas 2004; Royer and Dickenson 1999), which may cause problems in agricultural areas. However, it has also been noted that spreading dogbane may be effective in reclamation due to the soil binding abilities of the plant's rhizomes (Tannas 2004).

Five nuisance weeds (highlighted yellow in Table 6) were found sporadically throughout the Devonshire Beach study area. Quack grass (Agropyron repens) was found occasionally along the west-facing slope of the beach ridge near the groomed beach. Quack grass never formed a large 
component of the ground cover, but it was a noticeable species. Annual hawkweed (Crepis tectorum) occurred sporadically near the beach ridge road and occasionally near the base of the beach ridge. Only individual scattered plants were found. Fewer than five hemp-nettle (Galeopsis tetrahit) plants were found along the beach, near shoreline, approximately halfway between the groomed beach and the North Shore Day-use area. Dandelion was found in basically all habitat types at Devonshire beach, from beach habitats to more forested sites; however, it occurred only sporadically and never formed a major component of the ground cover.

Populations of rough cinquefoil were also found along the beach in several locations approximately 10-15 metres from shoreline. Generally, between two to ten plants would be found although the odd individual plant could also be found. This species was generally found in the ungroomed portions of the beach. Although this species is classified as a nuisance weed under the Alberta Weed Act (Province of Alberta n.d.), it is also a native species in Alberta. This species is known to be an increaser that requires exposed soil to become established (Tannas 2004; Royer and Dickenson 1999), which may pose problems in agricultural areas. However, it is known to occur naturally in the region (Moss 1983) and has also been recognized as an effective soil stabilizer (Tannas 2004).

Table 6. Non-native, invasive and designated weed species found in the Devonshire Beach study area.

\begin{tabular}{|l|l|l|}
\hline SCIENTIFIC NAME & COMMON NAME & STATUS \\
\hline Agropyron pectiniforme (R. \& S.) & Crested-wheat grass & Non-native (ANPC - invasive) \\
\hline Agropyron repens ((L.) Beauv.) & Quack grass & Nuisance weed \\
\hline Agrostis stolonifera (L.) & Redtop & Non-native \\
\hline Apocynum androsaemifolium (L.) & Spreading dogbane & Noxious weed (Native) \\
\hline Astragalus cicer (L.) & Cicer milk vetch & Non-native \\
\hline Bromus inermis var. inermis & Awnless brome & Non-native (ANPC - invasive) \\
\hline Cirsium arvense ((L.) Scop.) & Canada thistle & Noxious weed \\
\hline Crepis tectorum (L.) & Annual hawk's beard & Nuisance weed \\
\hline Festuca ovina (L.) & Sheep fescue & Non-native \\
\hline Galeopsis tetrahit (L.) & Hemp-nettle & Nuisance weed \\
\hline Medicago sativa (L.) & Alfalia & Non-native \\
\hline Melilotus alba (Desr.) & White sweet-clover & Non-native (ANPC - invasive) \\
\hline Melilotus officinalis ((L.) Lam.) & Yellow sweet clover & Non-native (ANPC - invasive) \\
\hline Phleum pratense (L.) & Timothy & Non-native (ANPC - invasive) \\
\hline Pinus sylvestris var. sylvestris (L.) & Scot's pine & Non-native \\
\hline Poa pratensis (L.) & Kentucky bluegrass & Non-native (ANPC - invasive) \\
\hline Potentilla norvegica (L.) & Rough cinquefoil & Nuisance weed (Native) \\
\hline Silene cucubalus (Wibel) & Bladder campion & Noxious weed \\
\hline Taraxacum officinale (Weber) & Dandelion & Nuisance weed \\
\hline
\end{tabular}

The remainder of the species listed in Table 6 are non-native species to Alberta. Some of the species are considered to be invasive by a number of sources (ANPC 2000), which could be an issue to maintaining the ecological integrity of the plant communities found in the Devonshire Beach study area. A number of these species were introduced to the area through the past reclamation programs which sought to reduce sand movement by increasing vegetative cover on patches of open sand. A monitoring program might be valuable, to ensure that these species do not out-compete native species causing a shift in native plant community species composition. 


\subsubsection{Rare and unusual plant survey}

Potentially two rare species were observed during the vegetation surveys of Devonshire Beach, including a likely observation of the Sitka willow (Salix sitchensis) ranked S1 by ANHIC, and a confirmed population of fox sedge (Carex vulpinoidea) along the shoreline of Lesser Slave Lake (ranked S2). The locations of these populations are provided in Appendix 2.

Dr. George Argus and Joyce Gould identified Sitka willow (Salix sitchensis) on Devonshire Beach in 2003. Dr. George Argus is a recognized expert in willow taxonomy and an Honorary Appointee of the Canadian Museum of Nature, upon his retirement from this institution. Joyce Gould is a botanist with the Alberta Natural Heritage Information Centre ANHIC). Sitka willow is ranked S1 by the ANHIC (Vujnovic and Gould 2002) indicating that five of fewer known populations of this species have been located in the province. In fact, the Devonshire Beach population may represent one of only two known locations in Alberta for this species; the other record being historical from the Whitecourt area in 1968 (ANHIC files 2004). Three attempts were made to relocate the Sitka willow identified by George Argus and Joyce Gould. One Sitka willow shrub was possibly located on August $12^{\text {th }}$ along the beach habitat. Two small branch specimens were collected for verification. While Dorothy Fabian (assistant curator of the University of Alberta Vascular Plant Herbarium) was relatively certain the leaves and branches collected were Sitka willow, she noted that catkins would be required for an absolute identification. Catkins were sought during all three field visits to the study area, however the timing was not such to capture the willow at time of flowering. A vegetative specimen will be sent to Dr. George Argus for expert identification.

A population of fox sedge (Carex vulpinoidea) was found along the shoreline of Lesser Slave Lake located approximately 500 - 700 metres south of the North Shore Day-use area. Approximately $40-60$ small clumps of the fox sedge were found where it occurred in relatively open patches in a willow thicket and adjacent to wetter areas dominated by rushes, bulrushes and cattails. This species is noted to require non-saline, non-acid soils that are permanently wet but receive some drainage (Kershaw et al. 2001). This species is currently ranked S2 by ANHIC, indicating that between 6 and 20 occurrences of this species are known in the province (Vujnovic and Gould 2002).

In addition to the two rare species observations, one moss species, false willow moss (Campylium hispidulum) was found in one site mixed in a patch of various Brachythecium species. False willow moss is currently ranked $\mathrm{S} 3$ although it does not occur on either the ANHIC tracking or watch lists (ANHIC 2002). A ranking of S3 indicates that between 21 and 100 occurrences are known in the province and the species may be rare and local throughout its range or it may be restricted in its range.

Giant wild rye (Elymus piperi) was also possibly found along the beach ridge road, although the specimen collected differs from the known morphological characteristics of the lemmas. Dorothy Fabian identified one grass specimen to likely be giant wild rye. Giant wild rye is a robust species forming large clumps and often reaching 2 to 3 metres in height (Moss 1983). Ms. Fabian noted that on the specimen provided the lemma were hirsute which is not a typical characteristic; Moss (1983) notes that giant wild rye lemmas are typically thinly pubescent to glabrous. This species is generally known to occur south of the Red Deer River where it is relatively common in the southern prairies and foothills (Moss 1983; Tannas 2003). Tannas (2003) noted that giant wild rye was found in moist sites along river banks, shrubby coulees, moist snow melt slopes or around springs or seeps. It is also noted that giant wild rye received recognition for its extensive rooting system, which has excellent soil binding properties (Tannas 2003). Consequently, with its general southern distribution and soil binding root system, it is possible that this species might have been introduced to the Devonshire Beach ridge area to aid in sand stabilization. Although this species has not been noted in either of the reclamation reports (Lesko 1974, BKA and Turner 1996) 
perhaps it was part of a seed mixture or part of an informal site reclamation program rather than a natural range extension. 


\subsection{Discussion}

\subsection{Site Evaluation}

Devonshire Beach within Lesser Slave Lake Provincial Park has long been renowned for its extensive sandy beaches and easy accessibility. Bradley (1980) identified Devonshire Beach and the beach ridge / sand dune / wetland complexes as provincially significant natural features and as unique habitats. This survey identified over 190 vascular plant, moss and liverwort species within a 4.5 kilometre stretch of shoreline. The high diversity of this area reflects the variety of landscape features and intergrades between habitat types that creates a wealth of unique microhabitats. Rare plants are most commonly found associated with unique micro- or seasonal habitats, unusual landscape features and transitional areas. Sites where rare plants are found are typically related to substrate, seasonal water patterns, small-scale landscape features and particular plant associations (Lancaster 2000). As such, the Devonshire Beach area has a high potential to harbour rare plant species due to the range in microhabitats, unique landscape features and numerous transitional areas.

Past reclamation efforts have introduced a number of species not native to the province or to the Lesser Slave Lake region. Furthermore, due to the relatively high use of the area and past use of motorized vehicles along the shoreline, several noxious and nuisance weeds were found. Despite these non-native, invasive and potentially invasive species, their total extent is not widespread throughout the study area and can likely be monitored to ensure that further spread into relatively natural areas can be prevented.

\subsection{Critique of Inventory Protocols}

The identification of Sitka willow on Devonshire Beach by Dr. George Argus and Joyce Gould in 2003 was a major factor in doing a more focused vegetation inventory along the beach. The extent of this willow on the beach was unknown and a focal point of this survey was to re-locate the willow and determine its extent along the beach. Unfortunately, while this survey possibly relocated the original willow found in 2003 (pending verification of vegetative specimen), no additional plants were found. This was in part due to the surveyor's inability to obtain catkins from the willow at the time of flowering. Although surveys were initiated in May, this species was not found at the time of flowering due to a lack of familiarity with this species' flowering times in Alberta. While three surveys during the course of a growing season are typically sufficient to capture most species at critical times (i.e. of plant development), the timing of these surveys was obviously not adequate to capture this species at its time of flowering.

Joyce Gould surveyed a larger portion Devonshire Beach in June of 2004, including a revisit to the 2003 Sitka willow site. While she also found only vegetative plants, she collected specimens from a number of suspected willow plants located along the beach. A map of her results is provided in Appendix 3. The specimens she collected were sent to George Argus for expert identification, which he confirmed were Sitka willow (Nepstad pers. comm. 2004). Ms. Gould's survey of the beach will be invaluable in determining the extents of this species along Devonshire Beach.

While a bryologist (Jennifer Doubt) was available to identify non-vascular samples that were collected, she did not accompany the surveyors in the field during their inventory. Geowest field surveyors have some skill in identifying mosses and liverworts, however the focus of individuals involved in this project leans more towards vascular plant identification. It is difficult for nonbryologists to identify certain species, particularly in the field as a microscope if often required to 
view diagnostic features. Furthermore, had a bryologist been involved in the field surveys, they would have been better able to identify potential habitats for rare non-vascular species.

\subsection{Project Limitations}

The study area covered for this project totaled approximately 60 - 65 hectares. While every reasonable effort was made to cover all the ground within the study area and create a complete species list, the list provided in this report is very likely incomplete. There are several factors that would influence the completeness of the species list, including the high diversity of the beach area, lack of a bryologist and general budgetary limitations. It should be also be noted that rare plant surveys can only confirm the presence of rare plants. Information from surveys in one year does not positively indicate that rare plants are absent from the survey area because flowering season may vary, distribution may be scattered, and some species may remain dormant in some years (Lancaster 2000).

While this study focused on a floristic inventory of the Devonshire Beach area, the leeward side of the primary dune and older dunes (outside of the park) were not included. These areas also represent unique micro- or seasonal habitats, unusual landscape features and transitional areas. As such, these areas would also have a high potential to harbour rare plant species due to the range in microhabitats, unique landscape features and numerous transitional areas.

\subsection{General Observations}

Invasive species are non-native plant species that once introduced into native habitats can not only survive but can also prosper. Invasive species have the potential to displace native plants by aggressive competition for resources, lack of co-evolved predators and pathogens, or even by direct chemical antagonism (alleopathy) against which native plants that did not co-evolve with them have no defense (ANPC 2000). Non-native invasive species can reduce biodiversity, essentially creating monocultures in undisturbed sites. Invasive species' ability to become established in native habitats impedes the objective of preserving native habitats, their interrelationships among species and their evolved resiliency and adaptation to natural disturbance and climatic variation (ANPC 2000).

Invasive and non-native species introduced to the Devonshire Beach area through past reclamation efforts may pose a problem in the future. While it is likely not practical to institute a program to remove the non-native and invasive species present on Devonshire Beach, their further spread could be monitored. Nolan Turner noted in 1996 that:

Though maintaining a completely 'natural' resource composed of totally native species in the proper compositions and able to be influenced by natural successional trends is a commendable goal, it is unrealistic to expect that the present plant community structure of the primary dune system will support the anticipated volume and type of site visitation. The use of 'unnatural' elements, including hard landscaping, topsoil and the use of more tolerant (to foot traffic) native and agronomic plants that enhance site capability for use or that provide for quick resource repairs will need to be considered (BKA and Turner 1996).

The fragile and highly erodible nature of the sand dunes does require that some compromise in site maintenance, from public use and visitation, and ecological integrity be made. 


\subsection{Recommendations}

Based on the high species diversity found at Devonshire Beach, the rare plant species found and the potential of the habitat to harbour rare plant species, several conservation / monitoring programs would be beneficial to maintain the high ecological integrity of area.

1. Invasive Species Monitoring / Vegetation Management Program - Invasive species could present a serious threat to the ecological integrity of the beach area. Numerous non-native and invasive species were introduced through past reclamation programs and pedestrian (and past vehicular) access to the area. As mentioned in section 4.4 , invasive species can affect native community composition, reduce biodiversity and ultimately change the habitats present at Devonshire Beach. This would not only affect the dynamics of the plant communities themselves, but also the fauna that relies on these habitats in addition to the local first nations who have historically used these communities. An invasive species monitoring or vegetation management program to deal with these invasive species may be a worthwhile investment if maintaining ecological integrity is a high priority. This type of program should target only non-native and invasive species.

2. Additional Rare Plant / Rare Community Surveys - The high diversity of this area reflects the variety of landscape features and ecotonal areas between habitat types that creates a wealth of unique microhabitats. Rare plants are most commonly found associated with unique micro- or seasonal habitats, unusual landscape features and transitional areas, and as such Devonshire Beach has a high potential to harbour rare plant species. Potentially two rare tracked plants (S1 and $\mathrm{S} 2$ ) have been identified along the beach and beach ridge. Any additional Sitka willow populations should be identified and additional fox sedge populations may also exist along the beach. As such, future surveys along the beach, both within Lesser Slave Lake Provincial Park and outside the park boundaries, would be definitely beneficial to provide context for these rare plant populations.

3. Dedicated Non-vascular / Bryophyte Survey - While the field surveyors had some skill at non-vascular plant identification and were able to identify certain species in the field and collect unknowns for later identification, this is often not sufficient to fully describe the non-vascular species composition of an area and capture the full range of rare non-vascular species. A bryologist would have greater knowledge and experience to identify rare non-vascular species and their potential habitats in the field.

4. Rare Species Monitoring Program - Due to high levels of public use of the beach and beach ridge complex, a monitoring program for known rare plant species would be beneficial. This program, with particular regards to the Sitka willow, would help to monitor the status of known rare species on the beach and how public use impacts these plants. This program would be almost critical should additional portions of the beach be groomed for public use.

5. Leeward Side of Dune / Wetland Complex - Furthermore, future surveys should include the leeward side of the dune system and associated wetland complexes as these areas would also represent unique landscape features.

6. Formal Re-vegetation Program - The previous re-vegetation attempts and monitoring efforts have been a fairly informal process. In order to maintain the beach dune system as a landform, reducing sand movement in certain areas is desirable. 
As such, a formal re-vegetation program could work towards this goal, through the installation and maintenance of snow fencing, to reduce sand movement, and seeding / transplanting of vegetation. The use of native Alberta species is recommended. An annual monitoring program would be beneficial for evaluating revegetation success. 


\subsection{Conclusion}

Devonshire Beach is a unique landscape feature within Alberta and a major tourist attraction for the community of Lesser Slave Lake and Lesser Slave Lake Provincial Park. Although a number of human disturbances are present on the beach ridge, which likely cannot be reversed, the site is still relatively intact and is worthy of preservation. This survey identified over 190 vascular plant, moss and liverwort species within a 4.5 kilometre stretch of shoreline. The high diversity of this area reflects the variety of landscape features and ecotonal areas between habitat types that creates a wealth of unique microhabitats. Rare plants are most commonly found associated with unique micro- or seasonal habitats, unusual landscape features and transitional areas, and as such Devonshire Beach has a high potential to harbour rare plant species.

Two rare plants, Sitka willow (Salix sitchensis) and fox sedge (Carex vulpinoidea) were found. The Sitka willow represents only one of two known locations for this species in the province of Alberta, while only between 6 and 20 sites of the fox sedge are known. 


\subsection{References}

\section{Literature Cited}

Alberta Energy / Forestry, Lands and Wildlife. 1990. Alberta Vegetation Species List and Species Group Checklists. Publication No. Ref-56, Edmonton, Alberta.

Alberta Native Plant Council (ANPC) 2000. A rogue's gallery of invasive non-native plants. Alberta Native Plant Council, Edmonton, Alberta. http://www.anpc.ab.ca

Alberta Natural Heritage Information Centre (ANHIC). 2002. List of all bryophyte elements. Alberta Community Development, Edmonton, http://www.cd.gov.ab.ca/preserving/parks/anhic/docs/bryophyte list.pdf.

Beckingham, J.D. and J.H. Archibald. 1996. Field Guide to Ecosites of Northern Alberta. Special Report 5, Canadian Forest Service, Northwest Region. University of British Columbia Press. Vancouver British Columbia.

Bradley, C. 1980. Lesser Slave Lake Provincial Park Biophysical Inventory and Resource Assessment. Resource Assessment and Management Section, Alberta Provincial Parks.

Butler Krebbes \& Associates and N.A. Turner. 1996. Big Lake Discovery Centre at Devonshire Beach, Lesser Slave Lake Provincial Park. Prepared for Big Lake Discovery Centre Project Steering Committee.

Kershaw, L., J. Gould, D. Johnson and J. Lancaster (eds.). 2001. Rare vascular plants of Alberta. Alberta Native Plant Council, University of Alberta Press, and The Canadian Forest Service. Edmonton, $A B$.

Lancaster, J. (ed.). 2000. Guidelines for Rare Plant Surveys. Alberta Native Plant Council. Edmonton, Alberta.

Lesko, G.L. 1974. Species suitability for sand dune reclamation at Lesser Slave Lake, Alberta. Information report NOR - X - 86, Northern Forest Research Centre, Canadian Forestry Service, Environment Canada. Edmonton, Alberta.

Moss, E.H. (revised by J.G. Packer). 1983. Flora of Alberta. University of Toronto Press. Toronto, Ontario. $687 \mathrm{pp}$.

Province of Alberta. No date. Alberta weed control act.

http://www1.agric.gov.ab.ca/\$department/deptdocs.nsf/all/acts4705?opendocument\#6. Accessed September 14, 2004.

Tannas, K. 2004. Common plants of the western rangelands - Volume 4: Forbs. Olds College and Alberta Agriculture and Rural Development. Alberta.

Tannas, K. 2003. Common plants of the western rangelands - Volume 1: Grasses and grass-like species. Olds College and Alberta Agriculture and Rural Development. Alberta.

Vujnovic, K. and J. Gould. 2002. Alberta Natural Heritage Information Centre Tracking and Watch Lists- Vascular Plants, Mosses, Liverworts, and Hornworts. Alberta Community Development, Parks and Protected Areas Division, Edmonton, Alberta. 38 pp. 


\section{Personal Communications}

Nepstad, Elaine. 2004. Elaine Nepstad is a Planning Officer with Alberta Community Development, Parks and Protected Areas, Grande Prairie, Alberta. Ms. Nepstad provided information on communications with and between Joyce Gould and Dr. George Argus. 


\section{Appendix 1 - Plant Species List by Habitat Type}




\section{VEGETATION DESCRIPTION - DEVONSHIRE BEACH}

SURVEYORS: NT, VC

DATE: May 17, June 23 2004, August 12

Plot Area: Beach

Species Code

\begin{tabular}{|c|c|c|c|}
\hline Shrub & Forb & Grass/Sedge & Moss \\
\hline ALNUTEN & ACHIMIL & AGROSCA & BRYUPSE \\
\hline CORNSTO & ACHISIB & ALOPAEQ & BRYUSPP \\
\hline PINUBAN & ANEMCAN & BECKSYZ & CERAPUR \\
\hline POPUBAL & APOCAND & CALACAN & CONOCON \\
\hline POPUTRE & ARTECAM & CALAINE & DREPADU \\
\hline RUBUIDA & ASTEHES & CAREBEB & LEPTPYR \\
\hline SALIBEB & ASTEPUN & CAREDEW & POHLWAH \\
\hline SALIBOO & CARDPEN & CAREUTR & \\
\hline SALICAN & CICUMAC & CAREVUL & \\
\hline SALIDRU & CIRSARV & ELEOACI & \\
\hline SALIEXI & CREPTEC & ELEOPAL & \\
\hline SALILAS & EPILANG & GLYCGRA & \\
\hline SALILUT & EPILPAL & GLYCSTR & \\
\hline SALIPET & EQUIARV & HORDJUB & \\
\hline SALIPLA & FRAGVIR & JUNCALP & \\
\hline SALIPRO & GALETET & JUNCBAL & \\
\hline \multirow[t]{19}{*}{ SALISIT? } & HIERUMB & JUNCNOD & \\
\hline & $\mathrm{KOCHSCO}$ & LUZUMUL & \\
\hline & LATHOCR & PHALARU & \\
\hline & MELIALB & PHLEPRA & \\
\hline & MELIOFF & POAPRA & \\
\hline & MENTARV & SCIRLAC & \\
\hline & PETASAG & SCIRMIC & \\
\hline & PLANMAJ & TYPHLAT & \\
\hline & POLYLAP & & \\
\hline & POTEANS & & \\
\hline & POTENOR & & \\
\hline & RUMEOCC & & \\
\hline & SCUTGAL & & \\
\hline & SILENOC & & \\
\hline & SISYMON & & \\
\hline & SOLICAN & & \\
\hline & SOLIGRA & & \\
\hline & TARAOFF & & \\
\hline & TRIFHYB & & \\
\hline
\end{tabular}

AGENCY: Geowest Environmental 
TRIFREP

URTIDIO

VICIAME

\section{VEGETATION DESCRIPTION - DEVONSHIRE BEACH}

SURVEYORS: NT, VC

AGENCY: Geowest Environmental

DATE: May 17, June 23 2004, August 12

Plot Area: Low Slope/Active Ridge

\section{Species Code}

Tree

BETUPAP

PICEGLA

PINUBAN

POPUBAL

POPUTRE

\begin{tabular}{|c|c|c|c|}
\hline Shrub & Forb & Grass & Moss \\
\hline AMELALN & ACHIMIL & AGROSTO & BRYUPSE \\
\hline ARCTUVA & ACTARUB & AGROSUB & CLIMDEN \\
\hline CORNSTO & ANEMCAN & AGRYCRI & DREPADU \\
\hline LONIDIO & APOCAND & AGRYREP & POHLWAH \\
\hline LONIINV & ARABGLA & BROMCIL & RHYTRUG \\
\hline PICEGLA & ARALNUD & BROMINE & Notes: Some of the \\
\hline POTEFRU & ARENLAT & CALILON & wetter species were \\
\hline PRUNVIR & ARETCAM & CARECUR & found in lower \\
\hline RIBEOXY & ARTEFRI & CARESIC & depressional areas \\
\hline ROSAACI & ASTECIL & DACTGLO & where the willow thicket \\
\hline ROSAWOO & CAMPROT & FESTOVI & meets the road. This \\
\hline RUBUIDA & CHENALB & FESTSAX & area is very flat and the \\
\hline SALIARB & CIRSARV & JUNCBAL & ridge is not readily \\
\hline SALIBEB & CORINIT & ORYZHYE & apparent (species found \\
\hline SALIDRU & CREPTEC & PHLEPRA & in the area include mint, \\
\hline SALIEXI & EQUIARV & POAPAL & avens, sedges, nettle, etc.) \\
\hline \multirow[t]{15}{*}{ SALIPLA } & EQUIFLU & POAPRA & \\
\hline & EQUIHYE & SCHIPUR & \\
\hline & EQUIPRA & & \\
\hline & ERYSCHE & & \\
\hline & FRAGVIR & & \\
\hline & GALIBOR & & \\
\hline & GEUMALE & & \\
\hline & HIERUMB & & \\
\hline & LATHOCR & & \\
\hline & MEDISAT & & \\
\hline & MELIALB & & \\
\hline & MELIOFF & & \\
\hline & MENTARV & & \\
\hline & POTEANS & & \\
\hline & POTENOR & & \\
\hline
\end{tabular}




PYROASP
SILECUC
SILENOC
SMILSTE
SOLIGRA
STELLON
STELLON
THALVEN
TRIFHYB
TRIFPRA
TRIFREP
URTIDIO
VICIAME

\section{VEGETATION DESCRIPTION - DEVONSHIRE BEACH}

SURVEYORS: NT, VC

AGENCY: Geowest Environmental

DATE: May 17, June 24, 2004, August 12, 2004

Plot Area: On Beach Ridge Slope

\section{Species Code}

\begin{tabular}{|c|c|c|c|c|}
\hline Tree & Shrub & Forb & Grass & Moss \\
\hline ABIEBAL & AMELALN & ACHIMIL & AGROREP & AMBLSER \\
\hline BETUPAP & ARCTUVA & ACTARUB & AGRYSMI & BRACCAM \\
\hline PICEGLA & CORNSTO & ANEMCAN & CALACAN & BRACSAL \\
\hline PINUBAN & CORYCOR & ANEMUL & CAREDEW & BRYOMIC \\
\hline PINUSYL & JUNICOM & APOCAND & CAREFIL & CAMPHIS \\
\hline POPUBAL & JUNIHOR & ARALNUD & CARESIC & CERAPUR \\
\hline \multirow[t]{15}{*}{ POPUTRE } & LEDUGRO & ARTECAM & ELYMPIP & DREPUNC \\
\hline & LINNBOR & ASTECIL & FESTSAX & EURHPUL \\
\hline & LONIDIO & ASTRCIC & FESTSCA & HYLOSPL \\
\hline & LONIINV & COMAUMB & ORYZASP & MNIUSPI \\
\hline & PRUNPEN & CORNCAN & ORYZPUN & PLAGCUS \\
\hline & PRUNVIR & DISPTRA & POAPRA & PLEUSCH \\
\hline & RIBEOXY & ELYMINN & & POHLNUT \\
\hline & RIBETRI & EPILANG & & POLYJUN \\
\hline & ROSAACI & EQUIARV & & POLYPIL \\
\hline & ROSAWOO & EQUIHYE & & PYLAPOL \\
\hline & RUBUIDA & FRAGVIR & & SYNTRUR \\
\hline & SALIBEB & GALIBOR & & TETRPEL \\
\hline & SALIPLA & GALITRF & . & THUIABI \\
\hline & SALISER & GALITRI & & TORTMUC \\
\hline & SYMPALB & GEOCLIV & & \\
\hline
\end{tabular}




$\begin{array}{ll}\text { VACCMYR } & \text { GEUMRIV } \\ \text { VACCVIT } & \text { LATHOCH } \\ \text { VIBUEDU } & \text { MAIACAN } \\ & \text { MELIOFF } \\ & \text { MITENUD } \\ & \text { ORTHSEC } \\ & \text { OSMODEP } \\ & \text { PETAPAL } \\ & \text { PLANMAJ } \\ & \text { PROSTRA } \\ \text { PYROASP } \\ \text { RUBUPUB } \\ \text { SMILSTE } \\ \text { TARAOFF } \\ \text { THALVEN } \\ \text { TRIEBOR } \\ \text { TRIFHYB } \\ \text { VICIAME } \\ \text { VIOLADU } \\ \end{array}$

\begin{tabular}{|l|l|l|}
\hline CODE & SCIENTIFIC NAME & COMMON NAME \\
\hline ABIEBAL & Abies balsamea ((L.) Mill) & Balsam fir \\
\hline ACHIMIL & Achillea millefolium (L.) & Common yarrow \\
\hline ACHISIB & Achillea sibirica (Ledeb.) & Many-flowered yarrow \\
\hline ACTARUB & Actaea rubra ((Ait.) Willd.) & Red and white baneberry \\
\hline AGROPEC & Agropyron pectiniforme (R. \& S.) & Crested-wheat grass \\
\hline AGROREP & Agropyron repens ((L.) Beauv.) & Quack grass \\
\hline AGROSCA & Agrostis scabra (Willd.) & hair grass \\
\hline AGROSMI & Agropyron smithii (Rydb.) & Western wheat grass \\
\hline AGROSTO & Agrostis stolonifera (L.) & Redtop \\
\hline AGROSUB & Agropyron trachycaulum var. subsecundum & Bearded wheat grass \\
\hline ALNUTEN & Alnus tenuifolia (Nutt.) & River alder \\
\hline ALOPAEQ & Alopecurus aequalis (Sobol.) & Water foxtail \\
\hline AMBLSER & Amblystegium serpens & Moss \\
\hline AMELALN & Amelanchier alnifolia (Nutt) & Saskatoon \\
\hline ANEMCAN & Anemone canadensis (L.) & Canada anemone \\
\hline ANEMUL & Anemone multifida (Poir.) & Cut-leaf anemone \\
\hline APOCAND & Apocynum androsaemifolium (L.) & Spreading dogbane \\
\hline ARABGLA & Arabis glabra ((L.) Bernh.) & Tower mustard \\
\hline ARALNUD & Aralia nudicaulis (L.) & Wild sarsaparilla \\
\hline ARCTUVA & Arctostaphylos uva-ursi ((L.) Spreng.) & Common bearberry \\
\hline ARTECAM & Artemisia campestris (L.) & Plains wormwood \\
\hline ARTEFRI & Artemisia frigida (Willd.) & Pasture sagewort \\
\hline ASTECIL & Aster ciliolatus (Lindl.) & Lindley's aster \\
\hline
\end{tabular}




\begin{tabular}{|c|c|c|}
\hline CODE & SCIENTIFIC NAME & COMMON NAME \\
\hline ASTEHES & Aster hesperius (A. Gray) & Western willow aster \\
\hline ASTEPUN & Aster puniceus (L.) & Purple-stemmed aster \\
\hline ASTRCIC & Astragalus cicer (L.) & Cicer milk vetch \\
\hline BECKSYZ & Beckmannia syzigachne ((Steud.) Fern.) & Slough grass \\
\hline BETUPAP & Betula papyrifera (Marsh.) & White birch \\
\hline BRACCAM & Brachythecium campestre & Moss \\
\hline BRACSAL & Brachythecium salebrosum & Moss \\
\hline $\mathrm{BROMCIL}$ & Bromus ciliatus (L.) & Fringed brome \\
\hline BROMINE & Bromus inermis var. inermis & Awnless brome \\
\hline BRYOMIC & Bryohaplocladium microphyllum & Moss \\
\hline BRYUPSE & Bryum pseudotriquetrum & Moss \\
\hline BRYUSPP & Bryum spp. & Moss \\
\hline CALACAN & Calamagrostis canadensis ((Michx.) Beauv.) & Bluejoint \\
\hline CALAINE & Calamagrostis inexpansa (A. Gray) & Northern reed grass \\
\hline CALALON & Calamovilfa longifolia (Hook.) Scribn. & Sand grass \\
\hline CAMPHIS & Campylium hispidulum & Moss \\
\hline CAMPROT & Campanula rotundifolia (L.) & Harebell \\
\hline CARDPEN & Cardamine pensylvanica (Muhl) & Bitter cress \\
\hline CAREBEB & Carex bebbii (Olney ex Fern.) & Bebb's sedge \\
\hline CARECUR & Carex curta (Good.) & Short sedge \\
\hline CAREDEW & Carex deweyana (Schwein) & Dewey's sedge \\
\hline CAREFIL & Carex filifolia (Nutt.) & Thread-leaved sedge \\
\hline CARESIC & Carex siccata (Dewey) & Hay sedge \\
\hline CAREVUL & Carex vulpinoidea (Michx.) & Fox sedge \\
\hline CAREUTR & Carex utriculata (Boott.) & Beaked sedge \\
\hline CERAPUR & Ceratodon purpureus ((Hedw.) Brid.) & Moss \\
\hline CHENALB & Chenopodium album (L.) & Lamb's quarters \\
\hline CICUMAC & Cicuta maculata (L.) & Water hemlock \\
\hline CIRSARV & Cirsium arvense ((L.) Scop.) & Canada thistle \\
\hline CLIMDEN & Climacium dendroides ((Hedw.) Web \& Mohr.) & Tree Moss \\
\hline COMAUMB & Comandra umbellata ((L.) Nutt.) & Bastard toad-flax \\
\hline CONOCON & Conocephalum conicum ((L.) Lindb) & Liverwort \\
\hline CORINIT & Corispermum nitidum (Kit.) & Bugseed \\
\hline CORNCAN & Cornus canadensis (L.) & Bunchberry \\
\hline CORNSTO & Cornus stolonifera (Michx.) & Red-osier dogwood \\
\hline CORYCOR & Corylus cornuta (Marsh.) & Beaked hazelnut \\
\hline CREPTEC & Crepis tectorum (L.) & Annual hawk's beard \\
\hline DACTGLO & Dactylis glomerata (L.) & Orchard grass \\
\hline DISPTRA & Disporum trachycarpum ((S. Wats.) B.\&H.) & Fairybells \\
\hline DREPADU & Drepanocladus aduncus ((Hedw.) Warnst.) & Brown Moss \\
\hline DREPUNC & Drepanocladus uncinatus ((Hedw.) Warnst.) & Brown Moss \\
\hline ELEOACI & Eleocharis acicularis ((L.) R.\& S.) & Needle spikerush \\
\hline ELEOPAL & Eleocharis palustis ((L.) R.\&.S) & Creeping spikerush \\
\hline ELYMINN & Elymus innovatus (Beal.) & Hairy wild rye \\
\hline ELYMPIP & Elymus piperi (Bowden) & Giant wild rye \\
\hline EPILANG & Epilobium angustifolium (L.) & Common fireweed \\
\hline
\end{tabular}




\begin{tabular}{|c|c|c|}
\hline CODE & SCIENTIFIC NAME & COMMON NAME \\
\hline EPILPAL & Epilobium palustre (L.) & Marsh willowherb \\
\hline EQUIARV & Equisetum arvense (L.) & Common horsetail \\
\hline EQUIFLU & Equisetum fluviatile (L.) & Swamp horsetail \\
\hline EQUIHYE & Equisetum hyemale (L.) & Common scouring-rush \\
\hline EQUIPRA & Equisetum pratense (Ehrh.) & Meadow horsetail \\
\hline ERYSCHE & Erysimum cheiranthoides (L.) & Wormseed mustard \\
\hline EURHPUL & Eurhnchium pulchellum ((Hedw.) Jenn.) & Moss \\
\hline FESTOVI & Festuca ovina (L.) & Sheep fescue \\
\hline FESTSAX & Festuca saximontana (Rydb.) & Rocky mountain fescue \\
\hline FESTSCA & Festuca scabrella (Torr.) & Rough fescue \\
\hline FRAGVIR & Fragaria virginiana (Duchesne) & Wild strawberry \\
\hline GALETET & Galeopsis tetrahit (L.) & Hemp-nettle \\
\hline GALIBOR & Galium boreale (L.) & Northern bedstraw \\
\hline GALITRF & Galium trifidum (L.) & Small bedstraw \\
\hline GALITRI & Galium triflorum (Michx.) & Sweet-scented bedstraw \\
\hline GEOCLIV & Geocaulon lividum ((Richards) Fern.) & Northern comandra \\
\hline GEUMALE & Geum aleppicum (Jacq.) & Yellow avens \\
\hline GEUMRIV & Geum rivale (L.) & Purple avens \\
\hline GLYCGRA & Glyceria grandis (S. Wats. ex A. Gray) & Common tall manna grass \\
\hline GLYCSTR & Glyceria striata ((Lam.) A.S. Hitchc.) & Fowl manna grass \\
\hline HIERUMB & Hieracium umbellatum (L.) & Narrow leaved hawkweed \\
\hline HORDJUB & Hordeum jubatum (L.) & Foxtail barley \\
\hline HYLOSPL & Hylocomium splendens ((Hedw.) B.S.G.) & Stair-step Moss \\
\hline JUNCALP & Juncus alpinoarticulatus (Chaix.) & Alpine rush \\
\hline JUNCBAL & Juncus balticus (Willd.) & Wire rush \\
\hline JUNCNOD & Juncus nodusus (L.) & Knotted rush \\
\hline JUNIHOR & Juniperus horizontalis (Moench) & Creeping juniper \\
\hline JUNICOM & Juniperus communis (L.) & Ground juniper \\
\hline $\mathrm{KOCHSCO}$ & Kochia scoparia ((L.) Schrad.) & Summer cypress \\
\hline LATHOCH & Lathyrus ocholeucus (Hook.) & Cream-colored vetchling \\
\hline LEDUGRO & Ledum groenlandicum (Oeder.) & Common Labrador tea \\
\hline LEPTPYR & Leptobryum pyriforme & Moss \\
\hline LINNBOR & Linnaea borealis (L.) & Twin-flower \\
\hline LONIDIO & Lonicera dioica (L.) & Twining honeysuckle \\
\hline LONIINV & Lonicera involucrata ((Richards.) Banks) & Bracted honeysuckle \\
\hline LUZUMUL & Luzula multiflora ((Retz.) Lej.) & Field woodrush \\
\hline MAIACAN & Maianthemum canadense (Desf.) & Wild lily-of-the-valley \\
\hline MEDISAT & Medicago sativa (L.) & Alfalfa \\
\hline MELIALB & Melilotus alba (Desr.) & White sweet-clover \\
\hline MELIOFF & Melilotus officinalis ((L.) Lam.) & Yellow sweet clover \\
\hline MENTARV & Mentha arvensis (L.) & Wild mint \\
\hline MERTPAN & Mertensia paniculata ((Ait.) G.Don) & Large-flowered lungwort \\
\hline MITENUD & Mitella nuda (L.) & Bishop's-cap \\
\hline MNIUSPI & Mnium spinulosum & Moss \\
\hline MOEHLAT & Moehringia lateriflora ((L.) Fenzl.) & Blunt-leaved sandwort \\
\hline ORTHSEC & Orthilia secunda ((L.) House) & One-sided wintergreen \\
\hline
\end{tabular}




\begin{tabular}{|c|c|c|}
\hline CODE & SCIENTIFIC NAME & COMMON NAME \\
\hline ORYZASP & Oryzopsis asperifolia (Michx.) & $\begin{array}{l}\text { White-grained mountain rice } \\
\text { grass }\end{array}$ \\
\hline ORYZHYE & Oryzopsis hymenoides ((R.\&S.) Ricker) & Indian rice grass \\
\hline ORYZPUN & Oryzopsis pungens ((Torr.) A.S.Hitchc.) & Northern rice grass \\
\hline PETAPAL & Petasites palmatus ((Ait.) A.Gray) & Palmate-leaved coltsfoot \\
\hline PETASAG & Petasites sagitattus ((Pursh) A.Gray) & Arrow-leaved coltsfoot \\
\hline PHALARU & Phalaris arundinacea (L.) & Reed canary grass \\
\hline PHLEPRA & Phleum pratense (L.) & Timothy \\
\hline PICEGLA & Picea glauca ((Moench) Voss) & White spruce \\
\hline PINUBAN & Pinus banksiana (Lamb.) & Jack pine \\
\hline PINUSYL & Pinus sylvestris var. sylvestris (L.) & Scot's pine \\
\hline PLAGCUS & Plagiomnium cuspidatum ((Hedw.) Kop.) & Moss \\
\hline PLANMAJ & Plantago major (L.) & Common plantain \\
\hline PLEUSCH & Pleurozium schreberi ((Brid.) Mitt.) & Schreber's Moss \\
\hline POAPAL & Poa palustris (L.) & Fowl bluegrass \\
\hline POAPRA & Poa pratensis (L.) & Kentucky bluegrass \\
\hline POHLNUT & Pohlia nutans ((Hedw.) Lindb.) & Copper wire moss \\
\hline POHLWAH & Pohlia wahlenbergii ((Web.\&Mohr) Andr.) & Moss \\
\hline POLYJUN & Polytrichum juniperum (Hedw.) & Juniper haircap \\
\hline POLYLAP & Polygonum lapathifolium (L.) & Pale persicaria \\
\hline POLYPIL & Polytrichum piliferum (Hedw.) & Awned haircap \\
\hline POPUBAL & Populus balsamifera (L.) & Balsam poplar \\
\hline POPUTRE & Populus tremuloides (Michx.) & Aspen \\
\hline POTEANS & Potentilla anserina (L.) & Silverweed \\
\hline POTEFRU & Potentilla fruticosa (L.) & Shrubby cinquefoil \\
\hline POTENOR & Potentilla norvegica (L.) & Rough cinquefoil \\
\hline PRUNPEN & Prunus pensylvanica (L. f.) & Pin cherry \\
\hline PRUNVIR & Prunus virginiana (L.) & Choke cherry \\
\hline PYLAPOL & Pylaisiella polyantha ((Hedw.) Grout) & Moss \\
\hline PYROASA & Pyrola asarifolia (Michx.) & Common pink wintergreen \\
\hline RHYTRUG & Rhytidium rugosum ((Hedw.) Kindb.) & Pipecleaner moss \\
\hline RIBEOXY & Ribes oxyacanthoides (L.) & Northern gooseberry \\
\hline RIBETRI & Ribes triste (Pall.) & Wild red currant \\
\hline ROSAACI & Rosa acicularis (Lindl.) & Prickly rose \\
\hline ROSAWOO & Rosa woodsii (Lindl.) & Common wild rose \\
\hline RUBUIDA & Rubus idaeus (L.) & Wild red raspberry \\
\hline RUBUPUB & Rubus pubescens (Raf.) & Dewberry \\
\hline RUMEOCC & Rumex occidentalis (S.Wats) & Western dock \\
\hline SALIBEB & Salix bebbiana (Sarg.) & Beaked willow \\
\hline SALIBOO & Salix boothii (Dorn) & Booth's willow \\
\hline SALICAN & Salix candida (Fleugge ex Willd) & Hoary willow \\
\hline SALIDRU & Salix drummondiana (Barr. ex. Hook) & Satin willow \\
\hline SALIEXI & Salix exigua (L.) & Sandbar willow \\
\hline SALILAS & Salix lasiandra (Benth.) & Western shining willow \\
\hline SALIPET & Salix petiolaris (J.E. Smith) & Basket willow \\
\hline SALIPLA & Salix planifolia (Pursh) & Flat leaved willow \\
\hline SALIPRO & Salix prolixa (Anderss.) & Mackenzie's willow \\
\hline
\end{tabular}




\begin{tabular}{|l|l|l|}
\hline CODE & SCIENTIFIC NAME & COMMON NAME \\
\hline SALISER & Salix serissima ((Bailey) Fern.) & Autumn willow \\
\hline SALISIT? & Salix sitchensis (Sanson ex Bong.) & Sitka willow \\
\hline SCHIPUR & Schizachne purpurascens ((Torr.) Swallen) & Purple oat grass \\
\hline SCIRMIC & Scirpus microcarpus (PresI) & Small fruited bulrush \\
\hline SCIRVAL & Scirpus validus (Vahl) & Common great bulrush \\
\hline SCUTGAL & Scutellaria galericulata(L.) & Marsh skulicap \\
\hline SILECUC & Silene cucubalus (Wibel) & Bladder campion \\
\hline SILENOC & Silene noctiflora (L.) & Night-flowering catchfly \\
\hline SISYMON & Sisyrinchium montanum (Greene) & Common blue-eyed grass \\
\hline SMILSTE & Smilacina stellata((L.) Desf.) & Star-flowered Solomon's seal \\
\hline SOLICAN & Solidago canadensis (L.) & Canada goldenrod \\
\hline SOLIGRA & Solidago graminifolia (L.) Salisb. & Flat- topped goldenrod \\
\hline STELLON & Stellaria longifolia (Muhl.) & Long-leaved chickweed \\
\hline SYMPALB & Symphoricarpos albus ((L.) Blake) & Snowberry \\
\hline SYNTRUR & Syntrichia ruralis & Moss \\
\hline TARAOFF & Taraxacum officinale (Weber) & Dandelion \\
\hline TETRPEL & Tetraphis pellucida (Hedw.) & Moss \\
\hline THALVEN & Thalictrum venulosum (Trem.) & Veiny meadow rue \\
\hline THUIABI & Thuidium abietinum ((Hedw.) B.S.G.) & Moss \\
\hline TORTMUC & Tortula mucronifolia & Moss \\
\hline TRIEBOR & Trientalis borealis (Raf.) & Northern starflower \\
\hline TRIFHYB & Trifolium hybridum (L.) & Alsike clover \\
\hline TRIFPRA & Trifolium pratense (L.) & Red clover \\
\hline TRIFREP & Trifolium repens (L.) & White clover \\
\hline TYPHLAT & Typha latifolia (L.) & Common cattail \\
\hline URTIDIO & Urtica dioica (L.) & Common nettle \\
\hline VACCMYR & Vaccinium myrtilloides (Michx.) & Blueberry \\
\hline VACCVIT & Vaccinium vitus-idaea (L.) & Bog cranberry \\
\hline VIBUEDU & Viburnum edule ((Michx.) Raf.) & Low-bush cranberry \\
\hline VICIAME & Vicia americana (Muhl.) & American vetch \\
\hline VIOLADU & Viola adunca (J.E. Smith) & Early blue violet \\
\hline & & \\
\hline
\end{tabular}




\section{Appendix 2 - Rare Plant Population Locations}




\begin{tabular}{|l|l|l|}
\hline Species & Easting & Northing \\
\hline Carex vulpinoidea & 642861 & 6136087 \\
\hline Salix sitchensis & 642727 & 6134626 \\
\hline
\end{tabular}




\section{Appendix 3 - Map of Joyce Gould's June 2004 Survey Results}




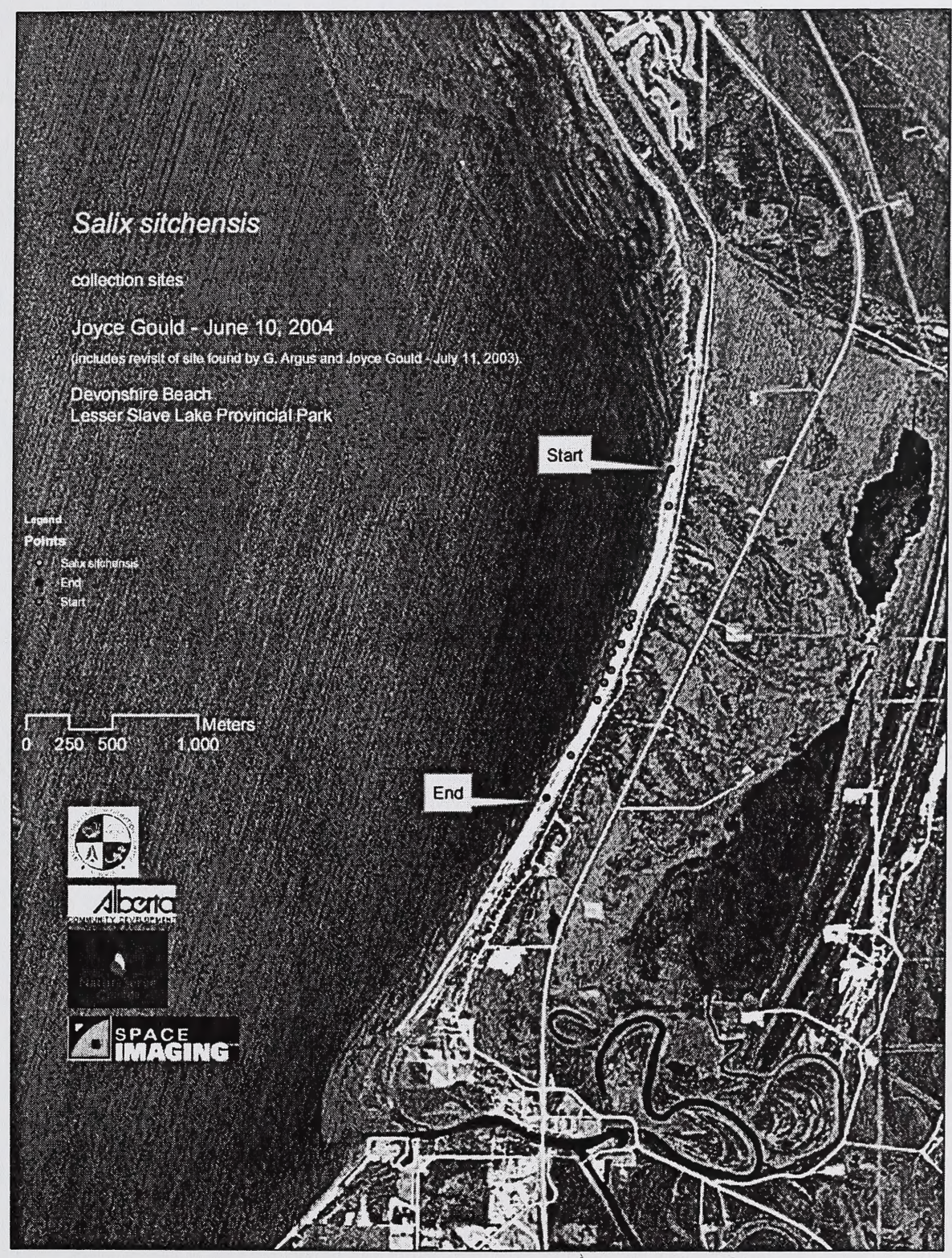




Library and Archives Canada

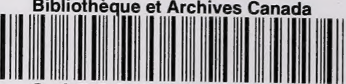

33286533611279 